\title{
POLLINATION ECOLOGY CHARACTERISTICS OF BARRINGTONIA RACEMOSA (L.) SPRENG. (LECYTHIDACEAE)
}

\author{
Jacob Solomon Raju ALURI *, Suvarna Raju PALATHOTI **, \\ Dileepu Kumar BANISETTI *** and Sravan Kumar SAMAREDDY *
}

* Andhra University, Department of Environmental Sciences, Visakhapatnam, India, IN-530003, solomonraju@gmail.com, sravankumarsamareddy@gmail.com

** International College of Engineering and Management, Department of Health and Safety Environmental Management, P. O. Box 2511, Pc 111, Muscat, Sultanate of Oman, raju@icem.edu.om

*** M. R. College (autonomous), Department of Botany, Vizianagaram, India, IN-535002, dillepbanisetti14@gmail.com

DOI: 10.2478/trser-2019-0017

KEYWORDS: Barringtonia racemosa, hanging racemes, late evening anthesis, hawk moth pollination, indehiscent fruits.

\section{ABSTRACT}

Barringtonia racemosa is an evergreen mangrove associate. It is an year-round bloomer that produces attractive pinkish-white flowers on long, hanging racemes. The flowers open during evening-night time during which only hawk moths swiftly visit them for nectar collection effecting both self- and cross-pollination. Fruits are large, single-seeded, indehiscent and buoyant, and disperse in the direction of tidal or ocean currents. Seeds are exposed only when fruits rot; when anchored in the muddy substratum, they germinate within two or three weeks to produce new plants.

ZUSAMMENFASSUNG: Charakteristische Merkmale zur Bestäubungsökologie von Barringtonia racemosa (L.) Spreng. (Lecythidaceae).

Barringtonia racemosa ist eine immergrüne Art der Mangrovengesellschaft. Sie blüht ganzjährig, wobei ihre attratktiven rosa-weißen Blüten lange, hängende Rispen bilden. Die Blüten öffnen sich zu Abend- und Nachtszeiten während denen sie nur flüchtig von Schwärmern zum Nektar saugen besucht werden und dabei Selbst- und auch Fremdbestäubung bewirken. Die Früchte sind groß, eingrifflig, geschlossen, schwimmfähig und verteilen sich in Richtung der Gezeiten- oder Ozeanströmungen. Die Samen werden nur dann freigelegt, wenn die Früchte sich zersetzen; wenn sie sich im schlammigen Substrat verankern, keimen sie innerhalb von zwei bis drei Wochen, wobei sich neue Pflanzen entwickeln.

REZUMAT: Caracteristicile ecologiei polenizării la Barringtonia racemosa (L.) Spreng. (Lecythidaceae).

Barringtonia racemosa este un component al mangrovelor sempervirescente. Înflorește de-a lungul întregului an, producând flori atractive, roz-alburii, pendente în raceme lungi. Florile se deschid seara-noaptea când doar molia-șoim le vizitează grăbit pentru colectare de nectar, efectuând atât autopolenizarea cât și polenizarea încrucişată. Fructele sunt mari, monoloculare, cu o singură sămânță, indehiscente, plutitoare și dispersate în direcția curenților marini sau oceanici. Semințele sunt etalate/eliberate doar la putrezirea fructelor; dacă se fixează în substratul mâlos, ele germinează în timp de două-trei săptămâni producând noi plante. 


\section{INTRODUCTION}

Mangrove forests are an important coastal resource and vital to the socio-economic development of coastal people. The mangroves are sources of highly valued commercial products and fishery resources and also as sites for developing a burgeoning eco-tourism (Kathiresan and Bingham, 2001; Sabai and Sisitka, 2013).

The importance of pollination ecology in other ecosystems is often widely known but there is little information on pollination and pollinators of mangroves in India and other parts of the world. Since the reproduction of mangroves depends on their pollination mode and pollinating agents, it is essential to study pollination ecology of mangroves to take measures for their restoration (Tomlinson, 1986; Mitra et al., 2014).

Tanaka (2004) reported that Barringtonia is a genus of 56 species with a wide distribution in the tropics from eastern Africa to northern Australia. The genus name commemorates Daines Barrington, an 18th century botanist, jurist and antiquary. Prance (2012) revised the genus and recognized 69 species. He noted that this genus has three distinct areas of species diversity, namely the Malay Peninsula, Borneo, and New Guinea. But, of all the species recognized, only three of them, B. asiatica, B. acutangula and B. racemosa are extremely widespread and occur in lowlands near the sea or beside streams and dispersed by water. Of these, $B$. racemosa is a widespread in the mangrove forests of India. The specific name refers to the long racemes on which the pedicellate flowers are borne (Chantaranothai, 1995).

Tanaka (2004) reported that records of pollinators of Barringtonia genus are sparse. Start and Marshall (1976) documented that Barringtonia sp. is pollinated by Mariana fruit bat, Pteropus mariannus in West Malaysia. Marshall (1983) noted that B. racemosa is pollinated by bats. He also mentioned that $B$. acutangula with shaving-brush type floral characteristics is probably pollinated by bats. Kato (1999) suggested that $B$. racemosa may be pollinated by bats in Japan. However, he noted that pollinators of this species have not been observed so far. Tanaka (2004) reported that B. racemosa is visited for nectar by four moth species, Asota heliconia riukiuana, Milionia basalis pyreri, Nevrina procopia and Erasmia pulchella fritzei in Iriomote Island, Japan. Of these, the first three visited the flowers only once while the last one visited twice during the observation period. Based on his field study, he stated that B. racemosa is probably pollinated by moths because its flowers were not visited by any other animals, including bats. Further, he attributed fruit-set in this species to the foraging activity of visiting moths.

Chantaranothai (1995) reported that B. racemosa is a coastal species that flourishes well under humid and moist conditions. It is distributed along tropical and sub-tropical coasts in South Africa, Mozambique, Madagascar, India, Sri Lanka, Malaysia, Thailand, Laos, southern China, northern Australia, coastal Taiwan, the Ryukyu Islands and Polynesian Islands. Boo Chich et al. (2006) noted that B. racemosa is rare in the wild and occurs in damp places in mangroves, tidal rivers, sandy and rocky shores and freshwater swamps in Singapore. Keng et al. (1998) reported that B. racemosa is listed as Critically Endangered on the Red List of threatened plants of Singapore. In India, it is distributed on the west coast from Konkan southwards through Karnataka, Kerala, Tamil Nadu, Sundarbans, and in the Andamans. Mahanti and Kumar (2017) reported that B. racemosa is a common and major species in the estuary situated adjacent to Poovar Island, the formation of which is a natural wonder because the lake, river, sea and beach meet the land. Arun et al. (2011) reported that B. racemosa is distributed in the Mangrove Reserve Forest in East Godavari District, Andhra Pradesh, India. The present study also found that this species occurs in this mangrove forest but it is a very rare one growing landward of the Coringa Estuary. Rajith et al. (2010) noted that this species is 
used in India as firewood and for its root decoction to stop bleeding during the post-delivery period. Pauku (2006) mentioned that B. racemosa is used as a good living fence and for treating venereal diseases in the Solomon Islands. Boo Chich et al. (2006) documented that B. racemosa is used for different purposes in Singapore. The powder of all parts of this plant is used as fish poison while the extract of these parts is an insecticide. The bark and root possess high tannin content and hence are used as tanning agents. This species is often cultivated as an ornamental tree in parks, gardens and along roadsides because its red and white flowers borne on long, hanging flowering shoots are attractive and provide aesthetic appeal (Umaru et al., 2018). Despite the importance of B. racemosa in traditional medicine and as a constituent of landward species of mangrove forest throughout its distribution range, there is a paucity of information on the pollination ecology of this species. Therefore, the present study was made to provide floral biology and pollination of this species as this information is important to know its sexual system, pollination syndrome, pollinators and fruiting aspects.

\section{MATERIAL AND METHODS}

Barringtonia racemosa (L.) Spreng. (Lecythidaceae) occurring in Godavari Coringa mangrove forest $\left(16^{\circ} 30^{\prime}-17^{\circ} 00^{\prime} \mathrm{N}\right.$ and $\left.82^{\circ} 10^{\prime}-80^{\circ} 23^{\prime} \mathrm{E}\right)$ located in Andhra Pradesh, India, was used for the study of floral biology and pollination aspects during June 2017 to July 2018. The morphological characters of flowers were recorded using 30 flowers collected at random. Flower-opening schedule was recorded based on ten days of field observations. Ten mature buds on five plans were used to record the time and mode of anther dehiscence. 25 mature buds were collected into a Petri dish and used subsequently to count the number of pollen grains per anther. The standard procedure given in Dafni et al. (2005) was used for calculating the pollen output per anther. Ten flowers were used to measure the average volume of nectar produced per flower and it was noted in $\mu \mathrm{l}$. Hand Sugar Refractometer was used to record sugar concentration in the nectar. The commencement and cessation of stigma receptivity was tested with $\mathrm{H}_{2} \mathrm{O}_{2}$ as given in Dafni et al. (2005). The insect species visiting the flowers were observed during day time from early evening to late night on different days in different months for the probing behaviour, forage collected, contact with sex organs that result in pollination and inter-plant foraging activity. Fruiting aspects such as fruit and seed characters, fruit dispersal and seed germination were observed in the field.

\section{RESULTS}

Barringtonia racemosa is commonly called "Powder-puff Mangrove Associate”. It is a medium-sized tree that grows in the landward side or edges of estuaries of mangrove forest (Fig. 1a). It is a medium-sized tree species propagated by seed and stem cuttings. The bark is silvery and smooth at the early growth stage and slowly develops fissures as it ages. The leaves are large and borne alternately, clustered at the ends of branches and appearing as in rosetteform. The midribs and branching veins are conspicuous on both sides of the leaves (Fig. 1b). Flowering occurs year-long without any concentrated flowering at any time of the year. However, the flowering is relatively sparse during the dry season when the plant sheds leaves for a short period. The flowers are produced on long hanging and pendulous racemes of almost one meter length; they open basipetally (Figs. 1c, 2a, b). They are short-stalked, large (35-45 $\mathrm{mm}$ long and 71 to $89 \mathrm{~mm}$ wide) and bisexual. The calyx is fused at the base and separated towards apex into four greenish pink sepals. The corolla consists of four elliptic free whitish 
petals but basally attached to the staminal tube. The stamens are numerous, long, white to pinkish and arranged in five-six whorls of which the innermost whorl is without anthers and all other whorls are with basifixed fertile anthers; they collectively form a large central mass extending into up to $40 \mathrm{~mm}$ diameter. The ovary is globular, two-four loculed and each locule contains one-two ovules. The style is simple, filiform, 20-50 mm long and tipped with obtuse stigma. A part of the style and the obtuse stigma extends beyond the height of stamens of all whorls from bud stage and during the entire life of the flower.
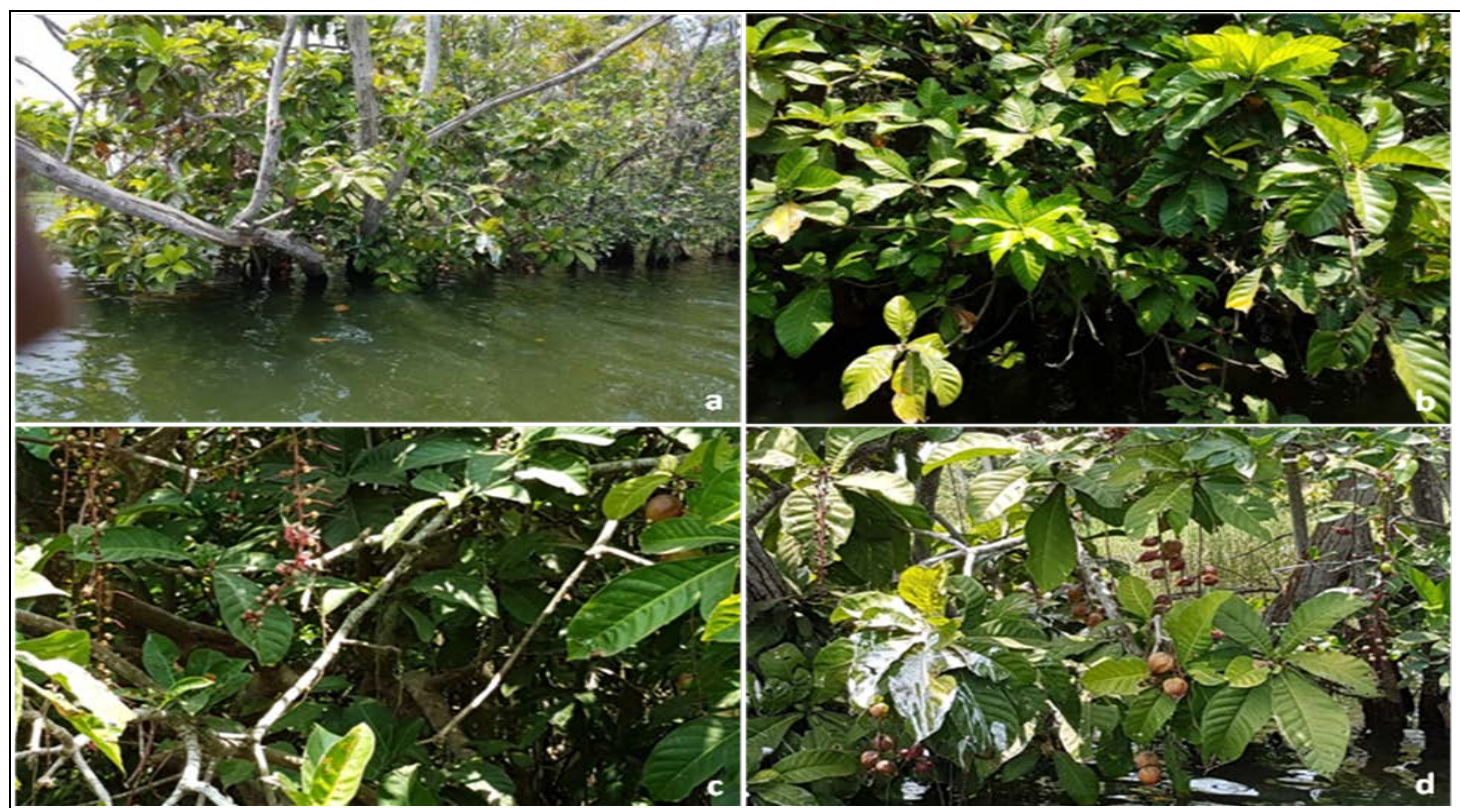

Figure 1: Barringtonia racemosa; a. Habitat; b. Foliage, c; Flowering phase; d. Fruiting phase.

The mature buds are pinkish-red and split open in the early evening to expose the huge mass of stamens in pink and white sprays and show full bloom during night time (Figs. 2c, d). At that time, they produce a pungent sweet odour which persists until the next day, remain open all night and the staminal mass falls off on the early evening of the next day. In a full grown raceme, almost half of the mature buds bloomed simultaneously. A flower produces 3.5 $\pm 1.2 \mu \mathrm{l}$ of nectar with $23-29 \%$ sugar concentration. With so many flowers opening at inflorescence level on the same day, individual plants secrete ample volume of nectar. The anther dehiscence occurs by longitudinal slits during flower-opening period and the stigma attains receptivity about an hour after complete flower-opening and ceases before sunrise on the following day. The pollen output varied from 659 to 980 grains per anther. With so many anthers at flower and inflorescence level dehiscing on the same day, individual plants supply huge amount of pollen for pollination. After the shedding of petals and staminal mass in individual flowers, the ants such as Camponotus sp. and Oecophylla sp. crowded at the flowers seeking nectar at the base of the corolla, but their role in pollination was found to be ruled out because the flowers were devoid of staminal mass. After the fall of petals and staminal mass from the flowers that opened on the previous day, the next batch of mature buds began to open gradually in the late evening and bloomed completely during which they were not crowded by ants. 


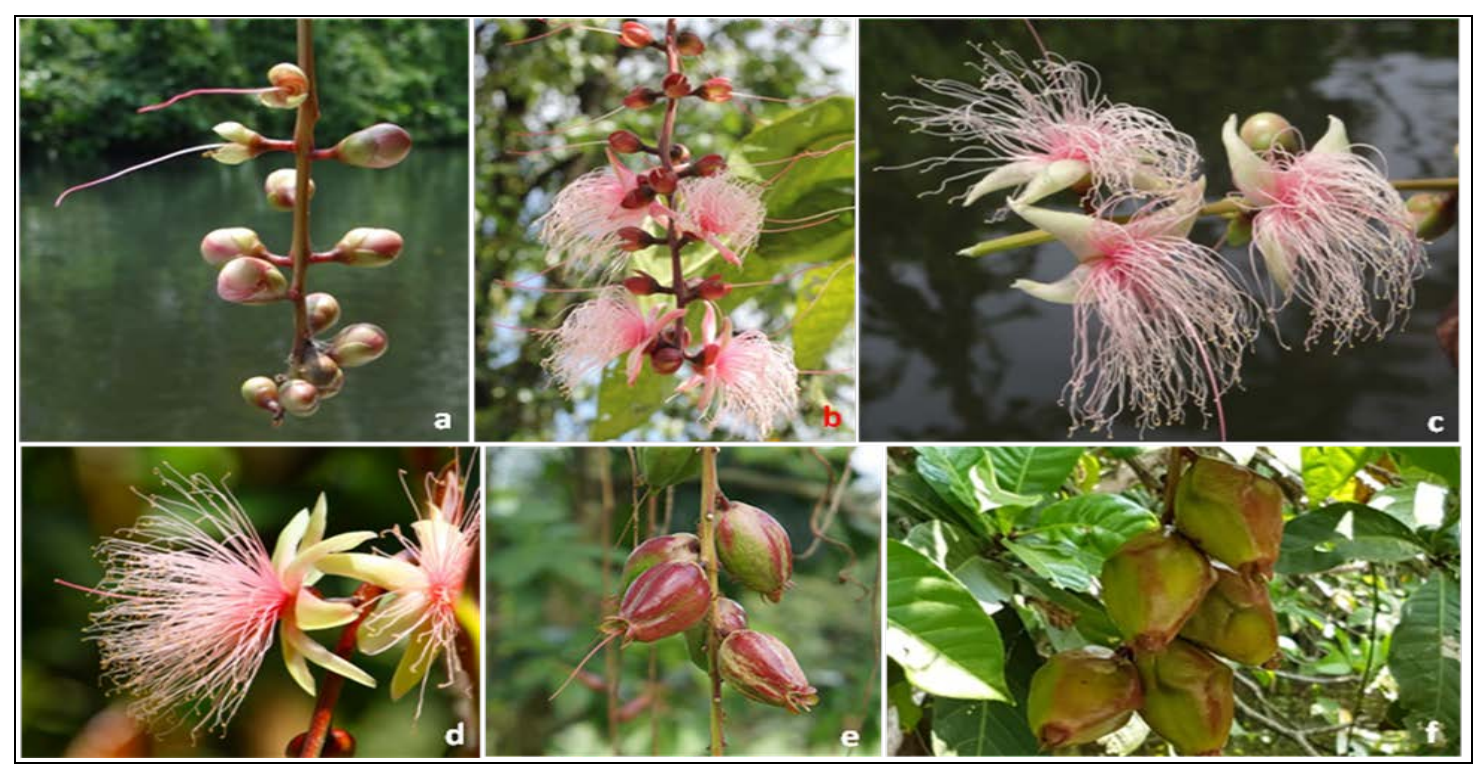

Figure 2: Barringtonia racemosa; a. Hanging inflorescence in bud phase; b. Inflorescence in flowering phase; c-d. Close-up view of flowers; e. Fruits in development phase; f. Fully developed fruits.

As soon as the mature buds opened, they were foraged for nectar by the hawk moths Agrius convolvuli L., Macroglossum sitiene Walker, M. gyrans Walker, Nephele hespera Fabr. and Hippotion rosetta Swinhoe. They visited the flowers very swiftly usually from base to top and occasionally from top to base. They hovered at the flowers, inserted the proboscis and obtained nectar in one to two seconds. In so doing, their proboscis, head and underside of wings contacted the stigma and stamens and this contact facilitated pollen transfer from the stamens to the moths and from moths to the stigma resulting in pollination. As they were swift fliers, they foraged numerous flowers on different racemes on different plants in quest of more nectar and thereby promoted the rate of cross-pollination. The foraging activity of moths ceased after 21:00 h. The flowers were not visited by any other animals later in the night and also on the next day, before the fall of the staminal mass.

The fruit is a tetragonous, 30-65 mm long indehiscent drupe tapering at the base and truncate at the apex (Fig. 1d). It is green initially and reddish when ripe but crowned by the persistent calyx. Each fruit contains a single 20-35 mm long aromatic seed surrounded by spongy and fibrous flesh (Figs. 2e, f). It floats and disperses by ocean currents for several months. After dispersal, the seed gradually gets exposed by rotting of fruit material, anchors in the substratum when soil is exposed and germinate within two-three weeks. The root appears from the calyx end and the shoot appears from the other end of the fruit. The seedling slowly grows to produce a new plant. 


\section{DISCUSSION}

The genus Barringtonia is a mangrove associate and distributed towards landward estuaries. It is an important species in estuaries due to its preference for humid and damp areas (Kabir et al., 2014). In the present study also, it is found growing in the landward Coringa Mangrove Forest but it has become very rare due to land use changes along the landward side of this forest. It is an evergreen tree species but displays a leafless state for a brief period during the dry season. But, it is a year-long bloomer and its pinkish-white flowers borne on long racemes are quite attractive from a very long distance; this species with its long flowering racemes add aesthetic appeal to the entire estuarine area.

Bat- and moth-pollinated plant species have been reported to have similar floral characteristics. Night-time blooming, brush-like or bell-shaped flowers with a strong fruity, soar or musty odour and large quantity of dilute nectar constitute bat-floral syndrome while night-time blooming, narrow-deep shaped flowers with strong or semi-strong aromatic odour and semi-large quantity of dilute nectar constitute moth-floral syndrome (Kato, 1993; Proctor et al., 1996). In Barringtonia racemosa the flower moths and bats in South Africa (Strey, 1976). In the present study, B. racemosa has been found to display night-time blooming, long and brush-like flowers on long hanging racemes, strong sweet odour emitted from the flowers upon anthesis and moderate quantity of semi-dilute nectar which collectively suggest mothfloral syndrome. In line with this, the flowers have been pollinated exclusively by hawk moths during late evening and early night period. As the moths are swift fliers, they forage numerous flowers on different plants, the foraging behaviour of which promotes cross-pollination rate. In Iriomote Island of Japan also, B. racemosa has been reported to be foraged and probably pollinated only by moths (Tanaka, 2004). The present study does not agree with the report by Marshall (1983) that B. racemosa is bat-pollinated. However, further studies are required throughout the distribution range of this species to define its pollinator classes according to their availability in respective mangrove habitats in different geographic regions. Thus, Tanaka (2004) expressed that bats are extinct on the Iriomote Island of Japan and this could be the reason for the absence of foraging visits of bats on B. racemosa on this island. In the present study area also, roosts of bats occur neither in the vicinity of the mangrove forest nor far away from the forest on land. Therefore, it is not unreasonable to suggest that $B$. racemosa with floral characteristics adapted for bat pollination is not pollinated by bats because of nonavailability of bats in the area. Therefore, B. racemosa is pollinated by moths or bats depending on their availability in the habitat.

It is important to note that the stamens are well exposed from the flowers of B. racemosa. But, the humid habitat is not conducive for making the pollen dry to powdery form for their easy dispersal by wind. Further, the basifixed arrangement of the anthers also does not facilitate for free movement of anthers to liberate pollen into the air. Hence, windpollination in this species can be totally ruled out. Apart from this, the pollen of B. racemosa is an important source for pollen-collecting bees such as honey bees and carpenter bees as each flower and raceme provides ample pollen. However, bee foraging activity was not observed on the flowers at the study area.

Strey (1976) reported that in B. racemosa, the flowers, after shedding petals and stamens are crowded with ants due to the presence of nectar around the ovary. In the present study also, Camponotus and Oecophylla ants crowd the flowers and racemes after shedding the petals and stamens, and feed on the left-over nectar around the ovary. Their feeding activity has no role in pollination but their presence may deter insects that cause harm to the ovary. 
Van Wyk and Van Wyk (1997) reported that B. racemosa produces fruits with a single seed which is enclosed by spongy and fibrous flesh. In the present study also, it was found that this species produces fruits with a single aromatic seed enclosed by spongy and fibrous material which provides them buoyancy and allows them to disperse in tidal water. Since the fruits are indehiscent, the seed remains inside and germinates only when the fruit rots and settles in the muddy substratum. After the seed anchors in the substratum, it germinates within two-three weeks and gradually produces a new plant.

\section{CONCLUSIONS}

Barringtonia racemosa is an evergreen mangrove associate species. It flowers yearlong and produces attractive pinkish-white flowers on hanging racemes. It is exclusively pollinated by hawk moths. Fruits are single-seeded, indehiscent and buoyant. They are dispersed by ocean currents and seeds upon rotting of fruits germinate within a short time to produce new plants. This tree species is valued for traditional medicine and as an ornamental due to its attractive flowers. It is suggested that its habitat should be enhanced with hawk moth larval host plant species in order to promote fruit set rate, especially through cross-pollination in this species.

\section{ACKNOWLEDGEMENTS}

We thank Dr. Venkata Ramana K., Young Scientist, DST-SERB, Dr. Prasada Rao C., Guest Faculty, Department of Botany, Andhra University, Visakhapatnam, for field assistance in mangrove forest. 


\section{REFERENCES}

1. Arun P. R., Murugeşan M. and Nikhil Raj P. P., 2011 - Impacts of proposed seismic survey operations on the avifauna and wildlife of reserve forest areas of KG basin project of oil India Limited, Salim Ali Centre for Ornithology and Natural History, Coimbatore, 39.

2. Boo Chich M., Kartini O.-H. and Ou-Yang C. L., 2006 - 1001 Gardens plants in Singapore, National Parks Board, Singapore, 501.

3. Chantaranothai P., 1995 - Barringtonia (Lecythidaceae) in Thailand, Kew Bulletin, 50, 677694.

4. Dafni A., Kevan P. G. and Husband B. C., 2005 - Practical Pollination Biology, Enviroquest Limited, Ontario, 90.

5. Kabir Z. K. M., Rahman M. S., Islam R. M., Paul P. K., Rahman S., Jahan R. and Rahmatullah M., 2014 - A review on a mangrove species from the Sunderbans, Bangladesh, Barringtonia racemosa (L.) Roxb., Amerian-Eurasian Journal of Sustainable Agriculture, 7, 356-372.

6. Kathiresan K. and Biningham B. L., 2001 - Biology of mangroves and mangrove ecosystems, Advances in Marine Biology, 40, 81-251.

7. Kato M., 1993 - Emergence of pollinators and evolution of bees, in Animals attracted by flowers, Inoue T. and Kato M. (eds), Heibonsha Limited, Tokyo, 33-78.

8. Kato M., 1999 - Symbiosis of plants and animals at night, in Natural history of flowers, Ohara M. (ed.), Hokkaido University Press, Sapporo, 74-88.

9. Keng H., Chin S. C. and Tan H. T. W., 1998 - The Concise Flora of Singapore: Monocotyledons, 2, NUS Press, Singapore, 215.

10. Mahanti P. and Kumar S., 2017 - Major biodiversity of Poovar Beach along the Neyaar River: a tourism destination of Kerala, India, International Research Journal of Environmental Sciences, 6, 72-75.

11. Marshall A. G., 1983 - Bats, flowers and fruit: evolutionary relationships in the Old World, Biological Journal of Linnean Society, 20, 115-135.

12. Mitra B., Biswas O., Roy S. and Chakraborti U., 2014 - Pollinators of mangroves in the perspective of Indian Sunderbans, ENVIS Newsletter, 21, 6-10.

13. Pauku R. L., 2006 - Species profiles for Pacific Island Agroforestry, 19, www.traditionaltree.org

14. Prance G. T., 2012 - A Revision of Barringtonia (Lecythidaceae), Allertonia, 12, 1-161.

15. Proctor M., Yeo P. and Lack A., 1996 - The natural history of pollination, Harper Collins Publishers, London, 479.

16. Rajith N. P., Navas M., Thaha A. M., Manju M. J., Anish N., Rajasekharan S. and George V., 2010 - A study on traditional mother care plants of rural communities of South Kerala, Indian Journal of Traditional Knowledge, 9, 203-208.

17. Sabai D. and Sisitka H., 2013 - Analysing learning at the interface of scientific and traditional ecological knowledge in a mangrove ecosystem restoration scenario in the eastern coast of Tanzania, Transylvanian Review of Systematical and Ecological Research, 15.2, 185-210.

18. Start A. N. and Marshall A. G., 1976 - Nectarivorous bats as pollinators of trees in West Malaysia, in Variation, breeding and conservation of tropical forest trees, Burley J. and Styles B. T. (eds), Academic Press, London, 141-150.

19. Strey R. G., 1976 - Barringtonia racemosa, The Flowering Plants of Africa, 43, 1706.

20. Tanaka N., 2004 - Pollination of Barringtonia racemosa (Lecythidaceae) by moths on Iriomote Island, Japan, Annals of the Tsukuba Botanical Garden, 23, 17-20.

21. Tomlinson P. B., 1986 - The botany of mangroves, Cambridge University Press, New York, 419.

22. Umaru I. H., Ahmed F. B., Umaru H. A. and Umaru K. I., 2018 - Barringtonia racemosa: phytochemical, pharmacological, biotechnological, botanical, traditional use and agronomical aspects, World Journal of Pharmacy and Pharmceutical Sciences, 7, 78-121.

23. Van Wyk A. E. and Van Wyk P., 1997 - Field guide to the trees of southern Africa, Struik, Cape Town, 732. 